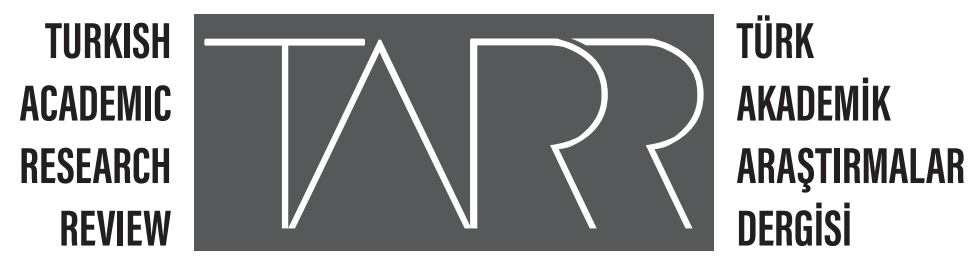

\title{
Instagram ve Mahremiyet: Dindar Muhafazakâr Kadınların Paylaşımları Örneği
}

Instagram and Privacy: The Case of the Sharing of Religious Conservative Women

\section{Bahset Karsl1 - Sezen Aycan}

Doç. Dr. Akdeniz Üniversitesi İlahiyat Fakültesi, bkarsli@akdeniz.edu.tr Orcid: 0000-0002-6810-0900

Yüksek Lisans Öğrencisi, Akdeniz Üniversitesi, Din Sosyolojisi, E-Posta: sezen_aycan1991@hotmail.com Orcid: 0000-0002-8217-8579

\author{
Makale Bilgisi | Article Information \\ Makale Türü-Article Type | Araştırma Makalesi / Research Article \\ Geliş Tarihi-Date Received | 23 Nisan / April 2020 \\ Kabul Tarihi-Date Accepted | 25 Haziran/June 2020 \\ Yayın Tarihi-Date Published | 30 Haziran / June 2020 \\ Yayın Sezonu | Nisan-Mayıs - Haziran \\ Pub Date Season | April-May-June
}

Atıf/Cite as: Karslı, Bahset-Aycan, Sezen, Instagram ve Mahremiyet: Dindar Muhafazakâr Kadınların Paylaşımları Örneği/Instagram and Privacy: The Case of the Sharing of Religious Conservative Women.tarr: Turkish Academic Research Review, 5 (2), 245-266 doi: tarr.725695

Intihal/Plagiarism: Bu makale, en az iki hakem tarafından incelenmiş ve intihal içermediği teyit edilmiştir. / This article has been reviewed by at least two referees and confirmed to include no plagiarism. https://dergipark.org.tr/tr/pub/tarr

Copyright (C) Published by Mehmet ŞAHİN Since 2016- Akdeniz University, Faculty of Theology, Antalya, 07058 Turkey. All rights reserved. 


\title{
Instagram ve Mahremiyet: Dindar Muhafazakâr Kadınların Paylașımları Örneği ${ }^{1}$
}

\author{
Bahset Karsl12 ${ }^{2}$, Sezen Aycan ${ }^{3}$
}

$\ddot{0 z z}$

Tarihten beri avcı, tarım, geleneksel, endüstri, modern ve postmodern gibi birçok toplum tasnifleri yapıla gelmiştir. İleri teknoloji ve bu teknolojinin gündelik kullanım pratiği, günümüz toplumunu dijital toplum şeklinde kavramsallaştırmaya yol açmıştır. Çünkü yeni teknolojik gelişmeler ile birlikte zaman-mekân bağlamında sınırların esnekleştiği, görme ve gösterme üzerine bir toplum modelinin inşa edildiği gözlemlenmiştir. Araştırmanın bu doğrultudaki amacı dijitalleşen toplumda dindarlık boyutuyla değişen yeni mahremiyet anlayışını yorumlamaktır. Araştırmanın belirlediği kapsam Instagram'dır. Örneklem grubu ise farklı şehirlerde yaşayan, Instagram'ı aktif kullanan ve takipçi sayısı elli binin üzerinde olan 31 muhafazakar dindar kadının paylaşımları olarak belirlenmiştir. Araştırmada nitel paradigmaya dayalı betimsel analiz ve fenomenolojik yaklaşım kullanılmıştır. Dindar muhafazakar kadınların paylaşımları örnekliğinde betimsel analiz ve fenomenolojik yaklaşım karşılıklı olarak kullanılmaya çalışılmı̧̧tır. Araştırma mahremiyet ve dindarlık boyutuyla gözlemlenen değişimi ele alması açısından önem taşımaktadır. Araştırmada farklı şehirlerde yaşayan dindar muhafazakar kadınların paylaşımlarla kendilerini gösterirken aynı zamanda dini kimlikleri çerçevesinde dindarlıklarını da gösterdiği sonucuna varılmıştır. Özellikle dindar muhafazakâr kadınlar, paylaşımlarında dini anlam, ifade ve sembollere sıklıkla yer vermişlerdir. Dindar Instagram kadın kullanıcılarının yaptıkları dini paylaşımlar çerçevesinde dindarlığı araçsallaştırarak kullandıkları sonucuna varılmıştır. Dijital alanda mahremiyetin dindarlık ile olan ilişkisi yeni bir anlam üretiminin göstergesi haline gelmiştir.

Anahtar Kelimeler: Dijitalleşme, Dindar Kadınlar ve Paylaşımları, Instagram, Gösterme ve Görünme, Mahremiyet

1 Bu makale "Dijital Dindarlıkta Mahremiyet, Dindar Muhafazakâr Kadınların Instagram Paylaşımları Örneği” adlı yüksek lisans tezi esas alınarak hazırlanmıştır.

2 Doç. Dr. Akdeniz Üniversitesi İlahiyat Fakültesi, bkarsli@akdeniz.edu.tr Orcid: https://orcid.org/0000-0002-6810-0900

3 Akdeniz Üniversitesi, Din Sosyolojisi Yüksek Lisans Öğrencisi, E-Posta: sezen aycan1991@hotmail.com Orcid: https:// orcid.org/0000-0002-8217-8579 


\title{
Title: Instagram and Privacy: The Case of the Sharing of Religious Conservative Women
}

\begin{abstract}
Throughout history, there have been made different societial classifications such as hunter, agricultural, traditional, industrial, modern and postmodern. Advanced technology and its everyday practices led to conceptualize today's society as digital society. This is because it has been observed that borders are getting flexible in the context of space and time with the new developments in technology. This causes a new type of social construction model based on seeing and showing. The aim of the research in this direction is to interpret the new understanding of privacy that changes with the dimension of religiosity in a digitalizing society. The scope of the study is Instagram. The sample group consists of sharing of 31 religious conservative women who live in different cities, are active users of Instagram, and have over 50k followers. The study uses a descriptive analysis based on qualitative paradigm and the approach is phenomenological. Descriptive analysis and phenomenological approach were tried to be used mutually in the example of the sharing of religious conservative women. The research is important in terms of addressing the change observed with the dimension of privacy and religiosity. In the study, it was concluded that religious conservative women living in different cities showed themselves through sharing, while at the same time showing their religiousness within the framework of their religious identity. Religious conservative women, in particular, often included religious meanings, expressions and symbols in their sharing. It has been concluded that religious Instagram female users use religiousness as a tool in the framework of their religious sharing. The relationship between privacy and religiosity in the digital field has become an indication of a new production of meaning. The relationship between privacy and religiosity in the digital field has become an indication of a new production of meaning.
\end{abstract}

Keywords: Digitalization, Religious Women and Their Sharing, Instagram, Demonstration and Appearance, Privacy.

\section{Giriș}

Toplumlar tarihsel geçmişlerinden bu yana farklı tipolojilerle adlandırılmışlardır. Coğrafi şartları, sosyokültürel durumları, dini inanç ve ritüelleri gibi faktörler, onların birbirleriyle aynı yapıya sahip olmadıklarını göstermektedir. Toplumları belli kriterlere göre ele aldığımızda karşımıza geleneksel toplum modeli çıkmaktadır. Geleneksel toplum avcı ve toplayıcılığa dayalı, kolektif bir yapının olduğu toplum modelidir. Toplumsal ilerlemeyle beraber sanayileşme ve kentleşmenin yaşanması modern toplumu inşa etmiştir. Modern toplumda rasyonel düşünme biçimiyle birey geleneksel yapıdan farklılaşmıştır. Hızla bilginin yayılması ve kullanılması modern toplum yapısını bir üst modele taşımıştır. 20. yy'da teknolojinin hakim olduğu ve bilgisayar ağlarına dayalı yeni bir toplum modeli ortaya çıkmıştır. Bu toplum ileri teknoloji ve dijital unsurların yaygınlıkla kullanıldı̆̆ı dijital topumu ifade etmektedir. 
İleri teknolojinin beraberinde getirdiği bilgisayar, internet ve akıllı telefon gibi yeni iletişim araçlarının kullanımı yaşadığımız toplumu dijital toplum modeli olarak adlandırılmasını sağlamıştır. Dijitalleşen toplumda bilgisayar, internet ve mobil cihazların kullanımı oldukça yaygindır. Dijital unsurların kullanımının toplumda hakim olması mekan-zaman bağlamında sınırları esnekleştirmiştir. Dijitalleşen toplumda sınırların esnekleşmesi görme ve gösterilmenin şeffaflaşmasıyla gerçekleşmiştir. Bu çerçevede mahremiyet algısı ve bu algının gösterdiği değişim, dijital toplum çözümlemelerinde önemli bir gösterge olarak kullanılabilmektedir. Özellikle dijital toplumda mahremiyetin uğradığı değişim sosyal medya kullanımında kendini göstermiştir. Çünkü sosyal medya kullanımında bireyler temel bilgilerine ve gündelik yaşam pratiklerine yer vermekte ve varoluşsal zeminlerine göndermeler içermektedirler. Bunun neticesinde sosyal medya üzerinde yeni sosyalleşme pratikleri gerçekleşirken mahremiyet alanı da kaçınılmaz bir şekilde bu pratiklerin icra edildiği gerçeklik ve sanallıklar arası geçişi içeren mekanlar haline gelmektedir.

Dijital toplum göstergesi olarak ele alınan mahremiyet algısı ve dönüşümü, genellikle sosyal medyayla birlikte ele alınmakta veya sosyal medya mahremiyet dönüşümünde önemli bir saha olarak görülmektedir. Sosyal medya mecralarında ise Instagram, diğer sosyal medya araçlarından daha fazla veri sunabilmektedir. Instagram'da yeni mahremiyet anlayışını ele almadan önce mahremiyet kelimesinin anlamını kavramsal çerçevede ele almak daha sistemli olacaktır. Öncelikle mahremiyet, kendi içerisinde çeşitli anlamları ifade etmektedir. Mahremiyet Arapça "haram” kelimesinden gelmektedir (Yaman, 2011: 185). "Mahrum”, "hürmet”, "muharrem”, "tahrim” gibi kelimeler de aynı kökten türetilmiştir. Özellikle mahrem kelimesi yasaklamak, men etmek, mahrum etmek, el sürmemek ve herhangi bir şeye dokunmamak anlamlarını taşımaktadır. İslamiyet'in bakış açısına göre mahremiyet kelimesi ele alındığında "haram, haram kılmak ve haram kılınmış gibi” anlamları taşımaktadır. Dini bir kavram olan mahremiyet Allah'ın yasakladığı, haram kıldığı ve evlenilmesi yasak olan kişileri de tanımlamaktadır (Dalkıç Örs, 2018: 6). Mahremiyet sözlüklerde gizlilik ve mahrem olma anlamlarında kullanılmaktadır. Türk Dil Kurumu mahremiyete gizlilik anlamını vermektedir (Aksan, 1998: 1487). Kubbealtı sözlüğü benzer bir şekilde mahremiyeti; "bir kimsenin gizli özelliği" olarak ele almıştır (Ayverdi, 2005: 1907). Ötüken Türkçe Sözlükte ise mahremiyet; "bir şeyin gizli yönü, bir kişinin özel yaşamına ilişkin gizlilik” anlamında açıklanmıştır (Çağbayır,2017: 680). Mahremiyet kelimesine dair yapılan tanımlar genel olarak gizlilik üzerinden açıklanmıştır. Gizleme, koruma, göstermeme, kişiye özel anlamda da ele alınmıştır.

Mahremiyetin bu tanımları bağlamında kimi zaman kesişen kimi zamanda farklılaşan yorumlamalar da söz konusudur. Samimi, içli dışlı, herkes tarafından bilinmemesi gereken, söylenmeyen, gizli anlamından hareketle Göle (2016: 128) mahremiyeti daha çok gizli aile hayat1, kadının çizdiği koruma alanı, bir kişiye veya bir eşyaya izinsiz bakış ve saklı kalması gereken şey olarak tanımlamaktadır. Sadece bireyin izni ve isteğiyle mahremiyet alanına girilebilir. Başka bir tanıma göre mahremiyet özel alanın diğer bir adıdır. Genellikle bireylerin kendileriyle baş başa kaldığı, düşüncelerini, davranışlarını, istediği zaman ve mekânda, istediği kişilerle sosyalleşme ilişkisini sürdürdüğü alandır (Yüksel, 2003). Aktaş’a göre mahremiyet bireyin kendisini keşfetmesi, duygu ve düşüncelerini, sahip olduğu yetenekleri maddi ve manevi anlamda geliştirebildiği bir kavramdır (1995: 12). Öztekin ve Öztekin'e (2010) göre mahremiyet bireyin bizzat 
kendisinin kurallarını ve sınırlarını belirlediği, kendisinin seçtiği insanlarla baş başa kaldığı, özgür yaşam alanı olarak tanımlamaktadır. Onlara göre bireyin mahremiyeti toplumsal denetim ve gözetimden uzak, tamamen kendilerine ait özel bir alandır. Çapçığlu ve Akın'a göre mahremiyet başkaları tarafından ne kadar bilindiğimiz ve başkalarının fiziksel olarak bize ne kadar ulaşılabildiklerinin yanı sıra, başkalarının ilgilerinin ne ölçüde nesnesi olduğumuzla da yakından ilişkili bir tanımdır (Çapcıoğlu \& Akın, 2019: 9). Mahremiyet bireylerin, grupların veya kurumların, başkalarıyla iletişimi gerçekleştirdiklerinde kendileriyle ilgili bilgiyi ne zaman, nasıl ve ne ölçüde vereceklerini belirleme hakkını vermektedir. Bireyin toplumsal yaşam biçimindeki şekline baktığımızda mahremiyet fiziksel veya psikolojik etkenler ile genel sosyal alanından gönüllü olarak çekilmesiyle ilişkilidir.

Mahremiyetle ilgili yapılan çeşitli tanımlardan da ortaya çıktığı gibi mahremiyeti genel, evrensel ve sınırları belirlenmiş bir şekilde açıklamak güçtür. Çünkü toplumlarda görülen sosyokültürel, coğrafya ve din gibi etkenlerin farklı olması mahremiyetin içeriğini de değiştirebilmektedir. Daha üst bir kavramsallaştırmayla mahremiyet en temelde yerel/yerli'dir. Örneğin Hilmi Yavuz, mahremiyetin sınırı: görmek mi, dokunmak mı? sorusundan hareketle Doğu kültüründe mahremiyetin görünmezlik Batı kültüründe ise dokunulmazlık olarak inşa edildiğini söyler. Batılı için, insan gövdesinin mahremiyeti, onun kamusal alanda, dokunulmaz olmasıla güvence altına alınmıştır. Mahremiyetin ihlali anlamında taciz ise, gövdeye dokunmakla gerçekleşir. Halbuki Doğu toplumları, mahremiyeti, dokunma duyusuyla değil, görme duyusuyla ilişkilendirir. Mahremiyet, mahrem olanın, ötekinin bakışından saklanması, ötekinin bakışına kapalı tutulmasıdır... Çünkü batı kültüründe, görme duyusu ile mahremiyetin ihlal edilmesi söz konusu olmuyor. Hilmi Yavuz, mahremiyetin sınırının başlama yerinin de aynı şekilde Batı kültüründe yakın, Doğu kültüründe ise $u z a k$ olduğunu söyler. Kısacası Batı toplumunda mahremiyet dokunulmazlığa denk gelirken, Doğu toplumunda görünmezliğe denk gelmektedir (Yavuz, 2012: 17-22). Doğu ve Batı toplumlarında her ne kadar farklı mahremiyet anlayışları görülse de bireyin temel gereksinimlerinden birini oluşturmaktadır. Bireyin yalnız kalma isteği, kendisiyle veya sevdiği insanlar ile özel vakit geçirmesi özel bir mahremiyet alanına olan ihtiyacı ortaya çıkarmıştır. Bu doğrultuda insanlığın varoluşundan ve toplumların tarihsel süreçlerinden bu yana belli bir özel alanı ifade eden bir mahremiyet alanının olduğunu söyleyebiliriz. Fakat toplumların tarihsel dönüşümüyle birlikte, daha özelde de birey merkezli toplumsallıklar yaygınlaştıkça mahremiyetin de değiştiği görülmektedir.

Mahremiyetin gösterdiği değişim sosyal medya kullanımından biri olan Instagram'da yeni bir anlam üretmiştir. Temelde gizlilik esasına dayalı olan mahremiyetin dindarlık boyutuyla olan ilişkisi Instagram'da paylaşımlarla gösterilen bir kullanım haline gelmiştir. Instagram kullanımında her türlü kullanıcı profili bulunmasından dolayı konumuza en uygun mahremiyet çözümlemesinde dindar muhafazakâr kadınların paylaşımlarının uygun veriler üreteceği düşünülmüştür. Bu çerçevede farklı şehirlerde yaşayan dindar Instagram kadın kullanıcıları belirlenmiş ve sistematik olma adına dindar Instagram kadın kullanıcıları tablolaştırılmaya çalışılmıştır. Dindarlık ve mahremiyet ilişkilerinin yorumlanmasında kullanılmak üzere araştırmada örneklem olarak belirlenen dindar muhafazakar kadınların medeni durumu, eğitimi ve yaşı profillerde yer alan bilgilere göre tespit edilmiştir. Çünkü dindar Instagram kadın kullanıcıların paylaşımlarında yaş, medeni durum ve eğitim seviyelerinde görülen farklılık mahremiyet 
anlayışlarını etkileme ihtimalini taşımaktadır. Diğer bir ifadeyle dindar kadınların toplumsal anlamda bulundukları farklı konumları ve gündelik yaşamındaki pratikleri mahremiyet anlayışlarını etkilemekte veya sosyal medya bu farklılıkları eşitleyebilmektedir. Nitekim dijitalleşmenin getirdiği görünme ve gösterilme özelliği sonucunda her ne kadar farklı şehirlerde yaşayan, farklı sosyokültürel özelliğe sahip olan dindar kadınlar bulunsa da benzer eylem ve pratiklerle bir araya geldikleri görülmüştür. Özellikle Instagram kullanımında görme ve gösterilmenin getirdiği normalleşme dindar kadın kimliğini dönüştürdüğü gibi mahremiyet anlayışlarını da değiştirmiştir.

\section{Araștırmada Kullanılan Yöntem ve Teknikler}

Araştırma nitel paradigmaya dayalı betimsel analiz ve fenomenolojik yaklaşım kullanılmak üzere dijital alanda Instagram'da dindar kadınların paylaşımları örnekliğinde değişen mahremiyet anlayışını içermektedir. Ele alınan paylaşımlarla mahremiyetin dijital alanda Instagram örnekliğinde yeniden anlam kazanması betimsel analiz ve fenomonolojik yaklaşımlarla değerlendirilmiştir. Betimsel analizde elde edilen veriler sistematik şekilde oluşturularak konuşma metinlerinin yazıya dökülmesi, alınan cevapların sınıflandırılması olarak belirlenmektedir (A1tunışık, 2010: 322). Fenomenoloji ise görüngübilimi olarak adlandırılan, Alman felsefeci Edmund Husserl tarafindan geliştirilmiş bir yöntem olarak tanımlanmaktadır. Fenomenoloji özü görme yöntemidir (Öktem, 2005: 28). Betimsel analiz ve fenomenolojik yaklaşım ile günümüz dijital toplumu analiz edilerek dijital toplum içerisinde esnekleşen zaman ve mekanın mahremiyeti değiştirme üzerindeki rolü ele alınmıştır. Instagram kullanımında yapılan paylaşımlar doğrultusunda mahremiyeti etkileme üzerindeki etkisi incelenmiştir.

Bu çerçevede araştırmada dindar kadınların paylaşımları, kullandıkları dini anlam ve semboller fenomenolojik ve betimsel analiz ile yorumlanmaya çalışılmıştır. İnstagram paylaşımlarında kullanılacak olan örneklemimiz ve örneklem kriterlerinin tablosu aşağıdadır.

Tablo 1 Dindar Muhafazakâr Instagram Kadın Kullanıcıları Örneği

\begin{tabular}{|c|c|c|c|c|c|}
\hline Yaşadı̆̆1 Şehir & Verilen Kod & Medeni Durum & Eğitim Düzeyi & Yaş & Takipçi Sayısı \\
\hline İzmir & X13 & Evli & Lisans & 26 & 731 Bin \\
\hline Sakarya & X5 & Evli & Lisans & 26 & 644 Bin \\
\hline Rize & X28 & Evli & Lisans & 25 & 444 Bin \\
\hline Kocaeli & X8 & Evli & Lise & 45 & 252 Bin \\
\hline Konya & X1 & Evli & Lisans & 27 & 247 Bin \\
\hline Van & X6 & Bekar & Lisans & 25 & 212 Bin \\
\hline Nevşehir & X24 & Evli & Lisans & 23 & 199 Bin \\
\hline Malatya & X16 & Evli & Lise & 35 & 173 Bin \\
\hline Bolu & X27 & Evli & Lisans & 26 & 172 Bin \\
\hline Trabzon & X4 & Evli & Lisans & 26 & 150 Bin \\
\hline Kayseri & X26 & Evli & Lise & 32 & 136 Bin \\
\hline
\end{tabular}




\begin{tabular}{|c|c|c|c|c|c|}
\hline Uşak & X21 & Evli & Lisans & 27 & 125 Bin \\
\hline Mersin & X17 & Evli & Lise & 35 & 120 Bin \\
\hline Karabük & X22 & Evli & Lise & 27 & 119 Bin \\
\hline Çanakkale & X20 & Evli & Lisans & 26 & 108 Bin \\
\hline Trabzon & X15 & Bekar & Lisans & 26 & 102 Bin \\
\hline Ankara & X10 & Evli & Lise & 29 & 100 Bin \\
\hline Tekirdağ & X29 & Evli & Lisans & 28 & 99 Bin \\
\hline Balıkesir & X9 & Evli & Lisans & 24 & 85 Bin \\
\hline Antalya & X12 & Evli & Önlisans & 26 & 79 Bin \\
\hline Samsun & X18 & Evli & Lisans & 32 & 78 Bin \\
\hline Mardin & X19 & Evli & Lise & 27 & 73 Bin \\
\hline İstanbul & X2 & Evli & Lisans & 27 & 69 Bin \\
\hline Adana & X32 & Evli & Lisans & 25 & 60 Bin \\
\hline İzmit & X14 & Bekar & Lisans & 25 & 59 Bin \\
\hline Şanlıurfa & X7 & Evli & Lisans & 29 & 57 Bin \\
\hline Diyarbakır & X23 & Evli & Lisans & 26 & 52 Bin \\
\hline Ordu & X30 & Evli & Lisans & 30 & 52 Bin \\
\hline Bursa & X3 & Evli & Lisans & 28 & 51 Bin \\
\hline Trakya & X11 & Evli & Lisans & 23 & 51 Bin \\
\hline Erzurum & X25 & Bekar & Lisans & 21 & 50 bin \\
\hline
\end{tabular}

\section{Mahremiyetin Tarihsel Dönüșümü}

Toplumların var oluşundan itibaren mahremiyet anlayışının olduğu belirlenmiştir. Toplumlar mahremiyet anlayışına göre belli bir kriter çerçevesinde ele alındığında ilk olarak karşımıza geleneksel toplum yapısı çıkmaktadır. Geleneksel toplum yapısının getirdiği coğrafi şartlar ve sosyo-ekonomik yapısı mahremiyet alanına zorunlu olarak bir ihtiyaç gereksinimini ortaya çıkarmamış veya var olan toplumsallık, geleneksel toplum zemininde mahremiyet algısı üretmiştir. Çünkü geleneksel toplum yapısında yer alan bireyler mekânın sınırlı olmasından dolayı ortak bir alanı kullanarak yaşamaktaydılar. Beraber yaşama ve birlikte hareket etmenin getirdiği kolektiflikten dolayı sosyal kontrolün güçlü olması ve bireyin kendini ifade etme özgürlüğünün olmaması mahremiyeti açıklama veya özele-bireye indirgenen mahremiyet talebi noktasında zorluk çıkarmıştır (Yüksel, 2003). Bireyin kendisine verilen rolü ve görevi yerine getirmesi, kendisinden daha çok diğer fertleri düşünerek hareket etmesi mahremiyeti bir farkındalık düzeyine ulaştırmamıştır.

İlerleyen toplumsal gelişmeyle beraber geleneksel toplum yapısından modern topluma doğru bir gelişme süreci yaşanmıştır. Toplumsal refahın artması, kentleşme ve sanayileşmeyle birlikte 
özel ve kamusal alan ayrımı ortaya çıkmıştır. Vincent'e göre mahremiyet kamusal denetimden uzak özel alanı temsil ederken, modern toplumda mahremiyet devlet karşısında yalnız kalma ihtiyacıdır (2016: 25). Bu doğrultuda modern toplumda iş dünyasının yoğun temposu ve devlet yapısının getirdiği katı kurallar bireyin kendisiyle baş başa kalma ve dinlenebileceği bir özel alana gereksinimi meydana getirmiştir. Modern toplumda özel alan bireyin yaşadığ ev, ev dışı alan ise kamusal alanı ifade etmektedir.

Modern toplum sonrası hızla gelişen yeni iletişim araçları ve teknoloji dijital toplum şeklinde kavramsallaştırılabilinen yeni bir toplum tipolojisini inşa etmiştir. Kullanılan yeni iletişim ve teknoloji ile birlikte özel ve kamusal alan ayrımı ortadan kalkarak esnek bir görünüm elde edilmiştir. Bilgisayarlar, akıllı telefonlar, mobil cihazlar ve tabletler gibi dijitalliğin unsuru olan yeni iletişim araçlarının kullanımıyla özel ve gizlilik esasına dayalı mahremiyet alanı görünme ve gösterilmeye doğru bir değişimi gerçekleştirmiştir. Esasında dijitalleşme, mahremiyette görünme ve paylaşmanın epistemolojik değişimine ilişkin yeni bir durumun varlığına göndermeler içermektedir. Oysa mahremiyetin dönüşümüne ilişkin anlama ve yorumlama kaygısı, toplum tipolojileri ve bu tipolojilerin ürettiği sosyallik/siyasallık bağlamında tartışıla gelmiştir. Mahremiyetin gösterdiği değişimi ele alan sosyologlardan biri olan Giddens (2014: 89), mahremiyeti bireyler arasında gerçekleşen iletişim olarak ele almıştır. Ona göre mahremiyet diğer birey tarafından içselleştirilmek değil, onun özelliklerini bilerek kendi özelliklerini ortaya koymak demektir. Mahremiyet her şeyden önce eşitlik bağlamında insanlarla ve bireyin kendisiyle kurduğu duygusal iletişim kurma sorunudur. Bireyin duygusal yakınlık kurduğu kişiler ile olan iletişim mahremiyet alanını belirtmektedir. Giddens (2014: 123-125) mahremiyetin alanını belirttikten sora mahremiyetin dönüşümünü modern toplum ve sonrasında kimlik ve cinsiyet rollerinin değişimi üzerinden yorumlamıştır. Kadın ve erkek arasında olan duygusal birliktelik ile gizli alan rol değişimiyle görünürlük kazanmıştır. Kadın duygusal yönünü ortaya çıkartarak mahremiyetin görünürlüğünü kolaylaştırmıştır.

Mahremiyetin dönüşümüne iktidar zemininde bakan Foucault'ya göre modern dönem toplumların denetimi ve gözetlenmesi, panoptikon modelindeki gibi (fiziki olarak yirmi dört saatini gözetleme imkanı veren hapishane modeli/fiziki denetleme) iktidarların zamansal ve mekansal kontrolü şeklinde icra edilmiştir. Yani toplum ve bireyler iktidar tarafindan gözetlenmektedir. Foucault'ya göre iktidar ilk zamanlarda gözetim şeklini somut ve sert bir şekilde uygulamaktaydı. Fakat zamanla ilerleyen yeni medya ve iletişim araçları sayesinde iktidar gözetimini yumuşatarak ve görünmeyerek denetimini yapmaya başlamıştır. Bu da bireylerin medyay1 kullanmasıyla gerçekleşmiştir (2012: 295). Yeni medya kullanımı ve medyada bulunma isteği gözetlenme durumunu normalleştirmiştir. Bireyler yeni medyada farklı kullanıcıların içeriklerini ve yorumlarını takip edip beğendikleri için, hem takip eden hem de takip edilen olarak, gözetimin bir taraftan öznesi, diğer taraftan ise nesnesi olmaktadır. Bireyin yeni medyada üretici, gözlemci, takipçi ve denetleyici olarak üstlendiği özne rolünün getirdiği görevden dolayı içerik tüketicisi olarak nesne konumuyla birlikte ortak hareket etmektedir. Diğer bir ifadeyle kişi, aynı anda hem gözetleyen hem de gözetlenen konumundadır. (Çapçıŏlu, 2019: 665). Yeni medya kullanımında bireyin gözetleyen ve gözetlenen konumunda olması sınırları esnekleştirerek kolaylıkla görünmeyi ve gözetlenmeyi ortaya çıkarmıştır. Görülmenin normalleşmesi aynı zamanda mahremiyetin de bilerek ve isteyerek gizlenmesine gerek duyulmadan gösterilme 
durumunu meydana getirmiştir. Bu doğrultuda yeni medya kullanımında mahremiyet alanına izin alınmadan ve korunmaya gerek duyulmadan görülebilme üzerine bir pratik inşa edilmiştir.

Mahremiyetin yeni medya üzerindeki değişimini ele alan Lyon ve Bauman (2017: 14) panoptikon sonrası gözetimi, akışkan gözetim olarak ifade etmişlerdir. Onlar, artık her şey akışkanlaşarak değişmeyen tek şeyin değişim olduğunu ve gittikçe her şeyin esnekleşerek belirsizleşmeye başladığını günümüz dijital toplumunu ele alarak açıklamışlardır. Akışkan gözetim bir yönelimdir; yani yeni bir gözetim yoludur. Bu yeni gözetim yolu da dijital teknolojik ürünler ve sanal güvenlik kontrolün sağlanması ile gerçekleşmektedir. Gündelik hayatın ayrılmaz parçası haline gelen kredi kartları, güvenlik kameraları, bilgisayar ve mobil cihazlar gözetim şeklini akışkanlaştırmıştır. Bununla birlikte sosyal meydanın sunduğu eğlenceli kullanım anlayışı ile bireyin temel bilgilerine kolaylıkla ulaşılabilmektedir. Bireyin temel bilgilerine ulaşılabilme durumu gizlenecek bir mahremiyet alanını bırakmamıştır (Bauman, 2013: 26).

Gizliliği ortadan kaldıran internet ve sosyal medya kullanımı mahremiyeti dönüştürmüştür. Mahremiyetin dönüşümündeki ana rol ise bireyin bilerek ve isteyerek özel alanını sosyal medya üzerinden paylaşma kullanımını ortaya çıkarmıştır. Sosyal medyanın sunduğu ucuz cep telefonu kameraları, sınırsız fotoğraf paylaşımı ve ücretsiz video kullanımı mahremiyeti kolaylıkla göstermektedir. Sosyal medyanın sunduğu görünürlük vaadiyle mahremiyetin görünümü toplumsal anlamda kabul edilmeyle de ilişkilidir (Bauman, 2016: 30). Simmel’e (2015: 34) göre mahremiyet, sır tutmaktır. Fakat günümüzde dijitalleşmeyle birlikte bilgiye kolaylıkla ulaşılması sırların sosyal medya üzerinde paylaşılmasıyla ortadan kalkmıştır. Adeta sırları söylemeye göstermeye dayalı olma anlayışı mahremiyetin gizli olma durumunu değiştirmiş ve ifşa ettikçe yani şeffaflaştıkça mahremiyetin ortadan kalkması veya genişlemesi/yenileşmesi şeklinde karşıtlıklar üzerinden anlaşılmaya çalışılmıştır.

Şeffaflaşma ve mahremiyet çözümlemesi noktasında mahremiyeti sosyal medya üzerindeki dönüşümü üzerinden ele alan Byung Chul Han'ın "Şeffaflık Toplumu” adlı eserinde bu kavramsal karşıtlığa odaklanmıştır. Ona göre günümüz dijital toplumu mahremiyeti şeffaflaştırmıştır. Şeffaflık özel alanın tümüyle elden çıkarılmasıdır ve içi görülebilir anlamına gelmektedir. Şeffaflık dijitalleşmeyle mahremiyeti çıplaklaştırarak göstermektedir. Boşluk bırakılmadan mahremiyetin gösterilmesi ise artarak devam etmektedir (2018: 12). Han sosyal medya üzerinde şeffaf bir şekilde mahremiyetin görünürlüğünü artan değer ilişkisiyle de ifade etmiştir. Mahremiyetin bu kadar artarak sosyal medyada gösterilmesi değerin de arttığı sonucunu vermektedir. Çünkü mahremiyet ve değer ilişkisinin artışı insan simasının gösterilmesine dayanmaktadır. İnsan siması sosyal medyada 'face' halinde gösterilerek mahremiyeti teşhir etmektedir. Face, Han'a göre bakışın aurasından yoksun bırakılıp teşhir edilen bir yüzdür (2018: 26-28). Teşhir edilen bir yüzün ana temasında güzelliği gösterme amacı bulunmaktadır. Bu nedenle sosyal medyada paylaş1lan insan yüzünde kötü, çirkin veya negatif bir durum yoktur. Tam tersine daha fazla yüz güzelleştirilerek mahremiyet alanına değer bir görünüm elde edilmeye çalışılmıştır. $\mathrm{Bu}$ doğrultuda Han'a göre her bir birey şeffaflık toplumunda mahremiyet alanının reklamını yapmaktadır. Bireyin mahremiyet alanı gösterim değeriyle ölçülerek (beğenme/like ve yorum sayısı) dışa açık bir şekilde görünümünü sergilemektedir. Sosyal medyada fotoğrafların paylaşılması, like ve yorum sayısının çokluğuyla değer kazanması mahremiyetin gizlilik boyutunu değiştirmiştir. Daha genel bir ifadeyle mahremiyet, sosyal medyada gizlenmeye gerek duyulma- 
dan aksine daha çok gösterme/görünmeyle anlamlı hale gelme denklemi üretmiş gözükmektedir. Bu anlamda görünmek ve var olmak mottosu, mahremiyetin yeni durumuna ilişkin yaygın algı1 örneklendirmektedir (bk. Atay, 2017). Görünmek ve var olmak bağıntısı sadece bedensel sunumu değil din, aile gibi kurumsal yapıları da kapsamaktadır. Mahremiyetin üretmiş olduğu bu yeni anlam, medya araçlarından daha fazla bireysel sunuma imkan veren örneklem sanal mekanımız Instagram'da gerçekleştiği için mahremiyet çözümlemesi açısından yoğun veriler sunduğuna inanılmaktadır.

\section{Sosyal Medya ve Mahremiyet: Instagram}

Instagram Kevin Systrom ve Mike Krieger tarafından 2010 y1lında kurulmuştur. Siklıkla fotoğraf ve video paylaşımına dayalı sosyal medya alanlarından biridir. Instagram İngilizce 'instant' yani Türkçesi ‘hızlı ve anlık olan' anlamına gelirken, İngilizce 'telegram' telgraf kelimesinin birleşiminden adını almıştır (Uzundumlu, 2015: 81).Instagram’ın diğer sosyal medya alanlarına göre bu kadar hızlı ve yaygın kullanımının nedeni, taşıdığı filtre özelliğidir. Bu paylaşılan video ve fotoğrafların değiştirilerek kullanıcılar tarafından eğlenceli hale getirilmesi özelliğidir (Hekimoğlu, 2019: 28).Instagram’ın görsel içeriğe sahip olması kullanıcı sayısını arttırmıştır. Çünkü Instagram'da beğeni ve takipçi sayısı ile her bir kullanıcı hızla popülerleşerek 'fenomen' kavramı çerçevesinde tanınma olanağını elde etmektedir.

Instagram kullanıcılarının hızla tanınmasıyla birlikte mahremiyet alanlarının görünümü de normalleşmektedir. Instagram kullanıcıları profillerini yarı açık veya tam kullanarak takipçilerine fotoğraf ve video yolu ile görünmeyi, beğenmeyi ve izlenmeyi amaçlamaktadırlar. Açık olarak kullanılan Instagram profilleri de keşfet bölümüne düşerek herkes tarafindan izlenebilmekte ve görülebilmektedir. Görülmenin artmasıla beraber Instagram takipçisi de doğal olarak artmaktadır (Aslanoğlu, 2016). Takipçi sayısının fazla olması kullanıcılar arasındaki görülmeyi şeffaflaştırmıştır. Bireyin Instagram kullanımında yaşadığı duygu durumundan özel hayatına kadar mahremiyet alanını göstermesi aynı zamanda beğenme ve haz duygusunu da arttırmıştır. Bu durum bir keresinden bir şey olmaz düşüncesiyle artarda özel hayata ilişkin mahrem alanların paylaşılmasına neden olmaktadır. Doğal olarak mahremiyetin görünümü normal hale dönüşmektedir (Hekimoğlu, 2019: 49).

Instagram kullanımı birey için görünür olmayı, takip edilmeyi ve beğenilmeyi ifade etmektedir. Bunun sonucunda bireyin Instagram'da elde ettiği popülerlik ve yaşadığı sanal değer daha fazla paylaşım yapma sıklığını ortaya çıkarmıştır. Birey bu çerçevede mahremiyetini bilerek ve isteyerek göstermektedir ve bu da mahremiyetin zedelenmesine neden olmaktadır (Yüksel, 2003). Özellikle Instagram kullanımının yaygınlaşarak mahremiyeti dönüştürme üzerindeki etkisi ele alındığında dindar kadın kullanıcıların paylaşımlarıyla mahremiyet alanlarını göstermeleri dikkat çekmektedir. Paylaşımlarında dini anlam, sembol ve ifadelere sıklıkla yer vermeleri mahremiyet ve dindarlık ilişkisinin yeni görünümünü yorumlama ihtiyacını ortaya çıkarmıştır. 


\section{Mahremiyetin Değișim Örneği: Instagram Paylașımları}

Instagram'da dindar kullanıcı kadınların sıklıkla artması ve yaptıkları paylaşımlar mahremiyetin dönüşümü noktasında dikkat çekici olmaktadır. Çünkü erkeğin Instagram’ı kullanması ve paylaşım yapması sosyalleşme olarak ifade edilirken, kadının paylaşımları mahremiyetin dönüşümü olarak ifade edilmektedir (Yavuz, 2012). Örneklem olarak belirlenen dindar kadınların Instagram paylaşımlarında geleneksel dindarlık kimliğinden dijital dindarlığa doğru bir kullanıcı profili karşımıza çıkmaktadır. Özel alanda yaşayan ve dini kimliği çerçevesinde belli bir mahremiyet anlayışı olan dindarlık tipinden artık kendini göstermeye çalışan yeni bir dindar tipi görülmektedir. Bu yeni dindar nesil tipi dijital alanı kullanan, dijital alanda sosyalleşme pratiklerini gerçekleştiren ve aynı zamanda bunu yaparken dini araçsallaştırarak mahremiyet görünümünü yumuşatan yeni bir dijital kullanıcılardır. Şimdi bu kullanıcıların yaptıkları paylaşımlarla mahremiyetin dönüşümü ve dindarlık ile olan ilişkisi ele alınacaktır.

\section{Dijitalleșen Dindarlık Görünümü}

Dijitalleşmenin toplum üzerinde belirleyici etkileri olduğu gibi birey üzerinde de etkileri görülmektedir. Görünme ve gösterilmeye dayalı olan dijital toplumda dindarlı̆̆ın görünümü de şeffaflaşmıştır. Bireyin dini kimliği çerçevesindeki dindarlık biçimi dijitalleşmeyle değişime uğramıştır. Öncelikle dindarlık dine ait inanç, ibadet ve sembollerle ilişkili olma ve onlarla zaman geçirme sıklığını ifade etmektedir (Kurt, 2009). Dindarlık dinin belirlediği temel ibadetleri yaşamın her alanına yayma ve belirlediği yasaklara uyma durumudur. Her dindarlık türü kendi içerisinde farklı bir görünüme sahiptir. Allport (2004: 50), dindarlığ 1 iç kaynaklı ve dış kaynaklı dindarlık olarak ele almaktadır. İç kaynaklı dindarlıkta bireyin temel yaşam alanında din yer alır. Birey dinin temel esaslarını içselleştirerek dinin bütün emirlerine uymaya çalışır. Birey için din bütün sorunlarla başa çıkma yoludur. Dış kaynaklı dindarlıkta ise birey istek ve amaçlarını gerçekleştirmek amacıyla dini araçsallaştırarak kullanmaktadır. Birey toplum tarafından beğeni ve takdir edilmek için dinin kurallarını yerine getirmektedir. Örneğin zayıflamak için oruç tutmak ve dışlanmamak amacıyla Cuma namazına gitmek dış dindarlığı ifade etmektedir (Ayten ve Köse, 2010: 120).

Birey dindarlı̆̆ını dijital alanın özelliğine göre göstermektedir. Dijital alanının içerisinde yer alan sosyal medya kullanımında dindarlık özlü söz, fotoğraf veya video yolu ile gösterilmeye dönüşmüş̧ür. Dijital alanda dinin görünümü ile birlikte dini bilgi ve pratikler de gösterilmektedir. Tespih çekmekten kurban kesmeye, dua etmekten namaz kılmaya kadar yapilan dini ibadetler dijital dindarlığa doğru bir görünümü yansıtmaktadır (Narmanlığlu, 2015). Dijital ibadetlerin hızlı ve kolay gerçekleşmesi sayesinde Müslümanlar dijitalleştirdikleri dijibadetlerini sosyal medya kullanımı üzerinden gerçekleştirmeye başlamışlardır. Cuma hutbesi okunurken çekilen selfieler, şeytan taşlama veya Kâbe ile olan yakınlığın fotoğraflanarak sosyal medyada yayılması dijital ibadet söylemine dönüşmüştür. Müslüman dindarlığın görünümü de dijital alanın özelliklerine göre paylaşılmıştır. Özellikle Müslüman dindar kadınların Instagram kullanımında fotoğraf paylaşımları ile birlikte metinsel olarak paylaştıkları yazılı metinlerde dindarlıklarını dijitalleştirerek göstermektedirler. Dindar Instagram kadın kullanıcıları dijital ibadetlerini paylaşımlarıyla gösterirken mahremiyet alanlarının görünümünü normalleştirmişlerdir. 


\title{
Gösterilen Dindarlık Cuma Paylaşımları
}

Müslüman dindar kadınların Instagram paylaşımları arasında yer alan Cuma paylaşımları, dijital dindarlığın görünümüne tipik birer örnek olarak verilebilir. Cuma günü Müslümanların ibadetlerini yaptıkları özel günlerden biridir. İslamiyet'e göre Cuma günü haftalık toplu ibadetlerin yapıldığı namazın adıdır. İslamiyet, Cuma gününün önemini, Müslümanların o gün için yapması gerekenleri ayet ve hadislerle açıklamıştır. Aynı adı taşıyan Cuma suresinde görüldüğü gibi “Ey iman edenler! Cuma günü namaz için çağrı yapıldığı zaman, hemen Allah'ın zikrine koşun ve alışverişi bırakın. Eğer bilirseniz bu, sizin için daha hayırlıdır” buyrulması Cuma'ya verilen önemi ifade etmektedir (Cuma 9/62). Cuma gününe ait bir Müslüman'ın nasıl davranması gerektiğine dair bilgiler de verilmiştir. Müslümanlar için oldukça önem taş1yan Cuma gününde farz olan namaz ile birlikte bedeni temiz tutmak, camiye erken gitmek ve Hz. Peygambere salâtü selam getirmek sünnet olarak kabul edilmiştir (Canbulat, 2018).Cuma gününün Müslümanlar için taşıdığı bu önem Instagram'a da yansımaktadır. Dindar Instagram kadın kullanıcıları düzenli olarak Cuma’ya dair özel dini paylaşımlarda bulunmaktadırlar.

\begin{abstract}
Allah'ım sen benim Rabbimsin. Senden başka ilah yoktur. Beni, sen yarattın ve ben senin kulunum. Ve ben iman ve kulluğumda gücüm yettiğince senin ahd-ü misakın üzereyim. Yâ Rabbi! Sen beni afv ü mağfiret eyle. Zira senden başka günahları afv ü mağfiret edecek kimse yok. Cumamız hayırlı olsun. Cumamız mübarek olsun, dualarda buluşalım dostlar. Amine Asya hepinizin Cumanızı hayırlı dileklerde bulunuyor. Maşallah boncuğuma (Ankara, X10).
\end{abstract}

Kim Kur'an'ı okur, öğrenir ve onunla amel ederse kıyamet günü, anne ve babasına nurdan bir taç giydirilir. Onun zıyası güneş ışı̆̆ı gibidir. Onun ana-babasına iki hulle giydirilir ki dünya onlarla boy ölçüşemez. Onlar: 'Ne karşıllı̆ında bunlar bize giydirilirdi?' derler. 'Çocuğunuzun Kur'an tutması sebebiyle' denilir. Hayırlı Cumalar. Rabbim sen evlatlarımızın Kur'an ehli insanlar olmasını nasip et, hayırlı nurlu Cumalar (Uşak, X21).

Cuma gününe özel Instagram'da yapılan dini içerikleri paylaşımlarda kadınlar dindarlıklarını söylem ile belirtmektedirler. Ayrıca Cuma paylaşımlarında kadınlar dindarlıklarını dini zaman ve mekâna bağlı olarak da göstermektedirler. Özellikle bu paylaşımlarında mekân olarak cami ve Kabe'nin fotoğraflanarak gösterilmesi dijital dindarlığın görünümünü araçsallaştırmaktadır. Dindar kadınların Cuma paylaşımlarında çocuklarını da göstermeleri takipçiler tarafından oldukça beğenilmektedir.

Aşk beş vakittir. Aşkımızın meyvesi Maşallah Muhammed Kadir’im \#Hayırlı Cumalar. Boş bulduğumuz seccadeleri dolduran gençlerden olursun (olursunuz) inşallah. Hayırlı cumalar (İstanbul, X2).

Çocuğun kalbi ekilmemiş tarlaya benzer; ne ekersen tutar kalbine şimdiden küçük tohumlar atanlardan olalım hayırlı cumalar (Konya, X1).

Ey Rabbim beni ve soyumdan gelecekleri namazı devamlı kilanlardan eyle; ey Rabbimiz duamı kabul et! İbrahim Suresi 40. Ayet (Trabzon, X4). 
Hiçbir anne-baba evladına iyi bir eğitimden, iyi bir ahlaktan daha değerli miras bırakamaz. Hayırlı cumalar. Bir amin bir de maşallahınızı alırız (İzmir, X13).

Selamünaleyküm, Muhammed Kadir ezan duyunca ellerini açıp Allah'ım anneme, babama, kardeşime, bana sağlık ver amin. Allah'ım annem, kardeşim evimize sağlıcakla gelsin. Çocuklarımıza vereceğimiz en büyük servet merhamet olmalı. Allah'ım kalp güzelliği versin. Hayırlı cumalar (Adana, X32).

Cuma paylaşımlarında dini anlam ve söylem ile birlikte çocuklar da dindarlığın bir görünümü olarak gösterilmektedir. Kadınlar kız çocuklarını tesettür kıyafetle, erkek çocuklarını ise namaz kılıyormuş gibi göstererek paylaşmaktadırlar. Instagram'ın yaygınlaşması ve oluşturduğu kullanım kültürü bu tarz dini anlam ve içeriğe dayalı paylaşımların sıklığını arttırmıştır. Kadınlar dindarlıklarını evlatları üzerinden sevgi ve merhamete dayalı bir içerikle ifade etmektedirler. Hayırlı evlat tanımı dua, namaz, secde, ayet ve hadislerle belirtilmektedir. Bu paylaşımlarda gündelik hayat gerçekliğinde kullanıla gelen dindarlık pratikleri ve fenomenlerini sanallaştırırken hem din merkezli sermaye üretip tedavüle sürmek hem de görünümüne aksesuarlar eklemeye çalıştıkları gözlemlenmektedir. Bu arada bedensel mahremiyet dönüşürken dini ve ailevi mahremiyetler de dijimarketlerde tüketime sunulması kaçınılmaz hale gelmektedir.

\section{Gizlenen Bedenin Dijital Görünümü}

Beden ile ilgili yapılan kavramlarda toplumların farklı anlayışları etkili olmuştur. Toplumların özelliklerine göre beden kimi zaman güzelleştirilen bir araç, kimi zaman ise nefsi terbiye etmeye dayalı kısıtlamalarla anlamlandırılmıştır. Antik çağ döneminde beden gücün sembolünü gösterirken, Orta çağda ruh ile ilişkilendirilerek ifade edilmiştir (Şişman, 2019: 34). İslam düşüncesine göre beden önemlidir. Bedeni korumak, temiz tutmak ve iyi işlerde kullanmak gerekir. İslam peygamberinin "Bedenin senin üzerinde hakkı var" sözü bedeni korumayla ilgili düşünceye açıklık getirmektedir (Harman, 1997: 256).

Beden mahrem ve genel olmak üzere iki farklı boyutta değerlendirilmektedir. Bedenin mahrem boyutu örtme, yani gizli tutma ve başkalarından sakınma anlamına gelmektedir. Bedenin genel boyutu ise sosyalleşme ve sosyal kimlik edinme ile ilişkilendirilmektedir. Dijitalleşen toplumda mahremiyet olan beden kavramı görme ve gösterilme üzerine anlam kazanmıştır. Bedenin görselleştiği alanlar yeni dijital kullanım alanları olmuştur. Dijitalleşmeyle sosyal medya kullanımında gösterilmeye dayalı bir kullanım kültürünün ortaya çıkması mahrem olan bedeni seyirlik hale dönüştürmüştür (Dolgun, 2008: 193). Dijital alanda bedenin görselleşmesiyle birlikte aynı zamanda bireye ait temel bilgilerin de yer alması sosyal medya kullanımının dayattığı isteklerdir. Bu çerçevede bireyin sosyal medyada aktifleşebilmesi ve bir kullanıcı olabilmesi için mahremiyetini düşünmeden temel bilgilerini paylaşması gerekmektedir. Yeni sosyalleşme pratiklerinin gerçekleştiği dijital alanda beden de mahremiyet alanını esnekleştirerek bir meta unsuruna dönüştürmüştür. Özellikle Instagram kullanımında paylaşımlar çerçevesinde dindar kadınların bedenlerini göstermeleri ve bunu da dindarlık kimliği çerçevesinde ifade etmeleri oldukça dikkat çekmektedir. 
Yüreği yangın yeri olup dilinden buraları eksik etmeyenlere de Rabbim nasip etsin en güzel zamanlarım. En güzel anılarım Umre'mden kabul olunan en güzel dualarım. Bu yazıyı neden paylaşıyorum? Belki nasiplenen olur, özellikle insanların kalbini diliyle kırmayı huy edinenlere, ölümlü dünya. 'Allah'u Teala çirkin hareketler yapan, çirkin sözler söyleyen kimseden nefret eder' (Tirmizi, Birr, 62). Bir Müslüman'ın, yanında bulunmayan din kardeşine yapacağı dua kabul olunur. Bir kimse din kardeşine hayır dua ettikçe, yanında bulunan görevli bir melek ona, 'Duan kabul olsun, aynı şeyler sana da verilsin' diye dua eder. (Müslim, Zikir 87, 88; İbni Mâce, Menâsik 5) Dualarımdasınız inşallah (Bursa, X3).

Yar’im, Yar bildiğim... Beşeri alemlerden yüreğime nakşeylediğim... Ey Leyl-i Lem Ey Katre-i Dem. Söyle şimdi hangi narın firkatı yakacak bu sineyi sensiz. Hangi kuyuya Yusuf olacak gönlüm ki Züleyha. Karş1lısıı sevecek beni kim İbrahim diye yakacak sinemi. Kim beni sen gibi hasretinle yollara davud edecek... Ah yar iste bu yüzden ben yine Bi'lâl hükmünde, bu sefer ben değil, minareler benim üstümde... Haydi al kuşak takıp gel hüznünle geceme, yüz görümlüğün ömrümdür. Tak beni boynuna yar, Rahman ve Rahim Olan ALLAH'ın aşkıyla. Ve gördük ki; mekân değildir, zamandır önemli olan. Ve lakin o da değildir, eylemdir önemli olan. Ve o dahi değildir kalp olmadıkça (Kayseri, X26).

Şu hayatta kalbinizin güzelliği kadar iyiliklerle, kalbinizin çirkinliği kadar da kötülüklerle karşılaşırsınız... Benim kendim için ve sizler için Allah’tan dileğim; herkes kalbinin ekmeğini yesin inşallah (Karabük, X22).

Dindar kadınların buna benzer paylaşımları Instagram'da sıklıkla görülmektedir. Bu paylaşımlarda kadınlar genellikle beden ile bireysel dindarlıklarını göstermektedirler. Bunu da özellikle kadınlar gittikleri Umre veya Hac ziyaretlerinde beden ile yaptıkları dini pratikleri ve eylemleri (Kabe'ye dokunma, rüku, secde, dua etme vb.) paylaşımlarıyla göstermektedirler. Dindarlığ1 ifade eden dini eylem ve bedenin görünümü inanç çă̆ından beğeniye, görünümden gösterilmeye dayalı bir anlamı ortaya çıkarmıştır. Bu anlamda dini aksesuarlar ve formlar bedensel sunumda araçsallaştırılmakta ve tüketime sunulmaktadır. Dini eylem ve pratiklerin Instagram'da bu şekildeki görünümü dindarlık çerçevesinde mahremiyet alanını değiştirmiştir. Dini kimliğe sahip ve belli bir dindarlığı yaşayan Instagram kadın kullanıcıları mahrem olan kutsal bedeni görülme üzerine anlamlandırmışlardır.

\section{Mahremiyetin Bedende Doğallaștırılması: Çekilen Selfieler}

Sosyal medyada sıklıkla selfie olarak adlandırılan fotoğraf paylaşımları yer almaktadır. Selfie kelimesi İngilizce bir kelimedir. Self sözcüğünün Türkçe karş1lı̆ğ kendi, kişisel anlamına gelmektedir. Selfie sözcüğünün İngilizce karşılı̆̆1 ise bireyin cep telefonu veya fotoğraf makinesiyle kendi kendini çekmesi ve kullandığı sosyal medyaya yüklemesi anlamında açıklanmaktadır. 2000'li yıllarda sosyal medyada hızla yaygınlaşarak paylaşılan ve özellikle kullanıcıların genç kız ve kadınlardan oluşması dikkat çekici olmuştur (Uzundumlu, 2015: 81). Son zamanlarda dindar Instagram kadın kullanıcıların paylaşımları arasında da görülmektedir. Fakat burada dindar kadınların selfie fotoğraflarında dini söylem ve ifadelere yer vermeleri dindarlık ve mahremiyet açısından yorumlanma ihtiyacını ortaya çıkarmıştır. 
Beyaz başörtümle sürekli Umre'den gelmiş gibiyim (Antalya, X12).

Olmuyorsa vakti değildir, hakkın değildir. Olmuyorsa hakkında hayırlı değildir (Erzurum, $\mathrm{X} 25)$.

Küsmeden, isyan etmeden sabredeceksin (Ordu, X30).

Yaprak döker bir yanımız, bir yanımız cennet bahçe (Malatya, X16).

Geceye dair son kelam, Allah büyük vesselâm (Mardin, X19).

Bir elin hissediş hikâyesidir bu satırlar. Gözler ellere takılır önce yardıma uzanacak ellere. El olmak lazım aslında yüreklere serpilen sevinç tohumları taşıyan. Ve yine el olmak lazım sevgiye aç olan kalpleri açmak için (Samsun, X18).

Velhasıl kelam; kalp herkeste var. Yürek denen başka bir şey... Mevlana Celaleddin-i Rumi (Mersin, X17).

Bu kadar şükredecek şey varken, neden çok şükürlük hayatların az şükürlü insanlarıyız? Hatta hiç bir şeyden memnun olamıyoruz (Şanlıurfa, X7).

Şeffaf=Saydam Yani diyor ki bir taraftan bakınca diğer tarafı görülen ya da artık kesinlikle görülmeyen mi demek lazım? Şeffaflıktan öyle uzağız ki artık. Oysa biz neysek oyuz. Doğru söylesek de, yalan söylesek de ne boyumuz uzuyor, ne kilomuz azalıyor. Kızım sana söylüyorum gelinim sen işit. Şeffaf olmak insana neler kazandırır, neler kaybettirir üzerinde tamamen durulması gereken bir konu. Ne çok saçmaladım değil mi öyle olaylarla karşılaşıyorum ki kelimelerim karman çorman oluyor. Allah bizleri doğru gerçek olanlardan eylesin. Amin (Bursa, X3).

Dindar Instagram kadın kullanıcıları selfie fotoğrafında bedene ait yüzü teşhir ederken, diğer yandan dini kimlikleri çerçevesinde dindarlıklarını yazılarla, nesnelerle ve sembollerle göstermektedirler. Ayrıca kullanıcı profilleri incelendiğinde akla Janmohamed'in (2018: 42) "Generetain M-Dünyayı Değiştiren Genç Müslümanlar” adlı çalışmasında kavramsallaştırdığı M nesli gelmektedir. Çünkü yeni M nesli geleneksel dindarlık kalıbından uzak kendini ifade eden, bilgili, yenilikçi, değişimlere ayak uyduran ve kendini gösteren bir nesildir. Bu doğrultuda dindar kadınların selfie paylaşımlarında gündelik hayatın içerisinde yer alan sevgi, şükür, dürüstlük ve hayata karşı mücadele etme gibi duygusal ifadeler dindarlı̆̆ın gösterimi içerisinde bulunmaktadır. Söylemsel ifadenin yanı sıra dindar kadınların selfie paylaşımlarıyla yüzün ayrıntılı bir şekilde gösterilmesi bedenin mahremiyet alanını şeffaflaştırmıştır. Yüz sanal alanda güzel olma odaklı gösterilen ve değerselleştirilen birer meta olarak kullanılmaktadır. Selfie paylaşımlarında yüzün makyaj ve filtre özelliği sayesinde güzelleştirilerek gösterilmesi mahremiyetin görünümünü esnekleştirmiştir. Selfienin yüzü güzel ve ayrıntılı göstermesi Instagram'da beğeni ve değeri arttırmaktadır. Bu çerçevede sıklıkla selfie paylaşımları yapılmaktadır.

Dindar Instagram kadın kullanıcıların selfie fotoğraflarında beden üzerinde yer alan, dini kimliği gösteren tesettür giyim ve nesnelerin tüketim kültürünün birer parçası olarak gösterilmesi mahremiyet alanını daha da saydam hale getirmiştir. Dindar kadın bedenin gizli yerlerini örten tesettür giyimin Instagram'daki paylaşımlarda gösterilme biçimi ve bunun mahremiyetin değişim ile olan ilişkisi yorumlanması gereken bir durumu meydana getirmiştir. 


\section{Tüketim Ekseninde Mahremiyeti Dönüștüren Dini sembol ve Nesnelerin Kullanımı}

Dijitalleşen toplumda mahrem olan bedenin görünmesi ve beden üzerinde bulunan nesnelerin de gösterilmesi, gerçekliğin kendisinden ziyade imajın önemini ortaya çıkarmıştır. Çünkü imaj görünme ve gösterişi barındırdığından dolayı birey kendini dijital alanın kullanımına bırakmaktadır (Okumuş, 2012: 163). Toplumun yaşam alanının merkezinde yer alan imaj, marka ve kullanılan popüler ürünler bireyin hem benliğini hem de dini kimliğini etkilemektedir. Bu çerçevede birey alışılmışın dışında farklı olmak ve popülerleşebilmek adına imaj kimliğine doğru sürüklenmektedir (Zorlu, 2006: 18). Dışsal görüntünün değer kazandığ1 imajlarda görüntülerden oluşan, görüntülere itaat eden ve görüntüler üzerinden gerçekleşen dijital ilişkiler yaşanmaktadır. Görüntülere dayalı yaşanan ilişkilerde imajı gösteren beden, kıyafet ve kullanılan nesneler de birer araç olarak kullanılmaktadır. Özellikle bireyin dini kimliğini yansıtan kıyafet ve kullanılan nesneler de imaj bir görüntüyü temsil etmektedir.

İmaj, görünümünü dijitalleşen topluma borçludur. Çünkü toplumsal ilişkiler ve yeni sosyalleşme pratikleri dijital alanda gerçekleşmektedir. Dijital alanda nesnelerin gösterilmesi ve reklamının yapılması tüketim kültürünün yeni bir versiyonunu gözler önüne sermiştir. Dijital alanda aranılan herhangi bir bilgi veya ziyaret edilen herhangi bir sitenin kayıtları tüketim kültürünün araçları tarafindan depolanmakta, gösteri profili oluşturularak görmek isteyen göstericilere tanıtılmaktadır. Böylece ihtiyaç olunmadığı halde bir ihtiyaçmı̧ gibi imajlaşan bir görüntüyü vermek adına nesneler gösterilmektedir. (Çapcığlu \& Akın, 2019: 599). Bireyin benliği, dini kimliği ve dindarlığı da dijital alanın gösterimine dönüşmüştür. Bunun sonucunda bireyin dindarlığı da gösterilme üzerine anlamlandırılmıştır. Dindarlığın gösteriş olarak sunulmasını sağlayan beş etmen bulunmaktadır. Bunlar; (i) beden, (ii) d1ş görünüş, kıyafet, (iii) söz, (iv) eylem, (v) bireyin çevre, sobbet erkanı ve ziyaretçi sayısından oluşmaktadır (Okumuş, 2012: 64-65). $\mathrm{Bu}$ beş unsur dijital alanın kullanım özelliğine göre değişim göstererek Instagram’da sıklıkla görülmektedir. Dindarlığını göstermek isteyen Instagram kullanıcısı hesabında beden, eylem ve dış görünüşünü fotoğraf ve paylaşımlar yoluyla gösterime sunmaktadır. Instagram'da görsel paylaşımların altına dini söz ve anlamlara yer vererek dindarlık Instagram takipçilerine gösterilmektedir. Dijital alandaki dindarlık imaj, gösteri ve gösteriş üzerinden değer kazanmaktadır. Instagram'ın sunduğu gösterme ve gösterilme, dindar kullanıcının Instagram sayfasında aktif olmasını ve paylaşımlarda bulunmasını dayatmaktadır. Bu doğrultuda dindar Instagram kadın kullanıcıları, dindarlığını söz ve eylemlerle, dış görünümünü tesettür giyim ve nesnelerle gösterirken mahremiyet anlayışına da yeni bir boyut kazandırmıştır. Dindar kadınların mahremiyet olarak değerlendirdikleri bedeni, Instagram’da yerini paylaşımlarla gösterilen imaja bırakmıştır.

Vicdanını kaybeden huzur aramasın. Eşarbım @vissona (İstanbul, X2).

Hayatımız kalbimiz gibi geçsin, ben kalbimden eminim ya siz? Yaka broşum@ikiyaka_accession (İzmit, X14).

Ben attığım adımla mükellefim, gerisi mi tevekkül. Allah'a emanet. Leoparı bu sene daha çok sevdim ben, eşarbım@vissona (İstanbul,X2).

Allah sadece kalbi verir, içini sen doldurursun. Kalbi güzel insanlara selam olsun (Diyarbak1r, X23). 
Derdimden büyük Allah'1m var çok şükür. Siyah aşktır (Erzurum, X25).

Bu aralar çok kullanıyorum sabır, dua, şükür. Eşarbım @vissona (İstanbul, X2).

Kabuğu kırılmış sedef üzüntü vermesin sana, çünkü içinde inci vardır (Malatya, X16).

Kalbinizle yaptığınız her şey size geri dönecektir. Havanın güzelliğine bir mavi abaya yakışır değil mi? (Bursa, X3).

İnsan diliyle değil, yaptığı işlerle konuşmalı. Siyah papatya abaya çıtçıtlı tam boy, kumaş şahane.(Erzurum, X25).

Şu abaya modelimi paylaşırken bugün şunu da yazmak istedim: Rabbim iyi insanlar ile karşılaştırsın (Bursa, X3).

Dua ettiğinizde çok isteyin. Çünkü vereceği hiçbir şey Allah’a ağır gelmez (Sakarya, X5).

Kıyafet ve beden üzerinde bulunan nesneler bireyin kültürel yapısını, etnik kimliğini ve hangi dini gruba ait olduğunu göstermektedir. Örneğin başörtüsü Müslümanlığı, kipa da Yahudiliği temsil etmektedir (Saad, 2012: 175). Dijital alanın kullanım alanlarından biri olan Instagram'da kadınlar dini kimliğini tesettür kıyafet ve kullandıkları nesnelerle birlikte yaptıkları paylaşımlarla takipçilerine sunmaktadırlar. Dindar Instagram kadın kullanıcıların bu paylaşımlarına bakıldığında şeffaf ve gösterilme üzerine yeni bir mahremiyet alanı üretilmiştir. Çünkü paylaşımlarda dindarlığı temsil eden kıyafet ve beden üzerinde yer alan nesneler gösterilirken modaya uygun, imaja dayalı bir görünüm gösterilmektedir. Moda yenilik, değişim ve farklılıklar üzerinden kendini inşa etme anlamını taşımaktadır (Zorlu, 2006: 8). Modaya uyumlu giyinen, yenilikçi ve değişime açık olduğunu ifade eden Instagram kadın kullanıcıları paylaşımlarla kendilerini gösterirken mahremiyet alanlarını da esnekleştirerek rahatlıkla görülebilen bir alan haline getirmişlerdir. Bunu da yaptıkları paylaşımlara dini anlam, söz ve sembollere yer vererek mahremiyetin görünümünü yumuşatmaya çalışmışlardır. Özellikle paylaşımlarda vicdan, dua, Allah, şükür vb. manevi hassasiyet taşıyan kelimelere sıklıkla değinmektedirler.

Dindar kadınların paylaşımları arasında özel hayatlarıyla ilgili bilgiler de yer almaktadır. Kadınlar paylaşımlarında eşe veya sevgiliye duyulan özel mahrem duygularını da Instagram profillerinde göstermektedirler. Özel alanda yaşanılan, hissedilen mahrem duyguların Instagram'da gösterilmesi son zamanlarda oldukça popülerleşen paylaşımlar arasında yer almaktadır. Dindar kadınlar yaşadıkları romantik duyguları dini anlamlarla ve ifadelerle helalleştirerek göstermeye çalışmaktadırlar.

\section{Romantikleșen Mahremiyet}

Dijitalleşen toplumda ileri teknoloji ve internetin kullanımı mahremiyetin görünürlüğünü arttıran birer gerçeklik haline gelmiştir. Mahremiyetin dijital alanda bu kadar kolay görünmesini sağlayan etmen ise sosyal medyada yapılan metinsel ve görsel paylaşımlardır. Paylaşımlarda birey, kendisini ön planda tutarak daha güzel ve dikkat çekici bir şekilde dijital alanda göstermeye odaklı olduğunu ifade etmektedir. Güzel olan dijital alanda beğenilmektedir. Bu doğrultuda dijital alanda çirkin, kötü veya mutsuz bir görüntünün aksine mümkün olduğunca en iyiyi ve gü- 
zeli paylaşma durumu söz konusudur. Dijital alan güzel olanı en pürüzsüz bir şekilde gösterme çabası içerisindedir (Han, 2018: 27-30). Güzelliğin gösterilerek beğeni kazanması mahremiyet alanının gizlilik boyutunu değiştirerek görünme üzerine bir anlam üretmiştir.

Dijital alanda güzel görünme isteği özellikle Instagram kullanımında görülmektedir. Kullanıcılar profillerindeki paylaşımlarla kendilerini ve dini kimliklerini yansıtmaktadırlar. Özellikle dini kimlikleri doğrultusunda dindarlıklarını göstermeye çalışan Instagram kullanıcıları profillerinde Kâbe veya cami paylaşımlarına yer vermektedir. Bu tür paylaşımları dindar muhafazakâr kadınlar sıklıkla yapmaktadır. Dindar kadın; başörtü, cami, namaz, iman, dua gibi dini içerikli fotoğraf paylaşmaktadır. Dindar kadın gündelik hayatını dini anlamlarla ifade ettiği gibi söz, nişan, düğün gibi toplumsal eylemleri, İslami yaşam tarzına uygun bir şekilde camide gelinlikle paylaşımını yaparak gerçekleştirmektedir (Özel, 2018). Kadın kullanıcı dindarlık imajını Instagram'da dini sözler ve sembollerle göstermektedir. Dindar kadınların Instagram paylaşımları incelendiğinde karşımıza eşi, nişanlısı veya sevgilisi hakkında yaptığı romantik dini paylaşımlar çıkmaktadır.

Şükürler olsun masalımı ilmek ilmek dokuyan Rabbe dini nikâhımız (Trabzon, X15).

Nikâhımız önce göklerde kıyıldı, Rabbim mübarek kılsın Amin (İstanbul, X2).

Bir ömür çayını demlerim, derdini dinlerim, dualarıma seni de eklerim (Ordu, X30).

Allah hayallerimizi dua, dualarımızı da kabul eylesin, Mevlana’nın dediği gibi (Uşak, X21).

Allah'ım hayalime bile günah girmesin (Konya, X1).

Rabbim cennetinde de bizi bir k1lsın; ayırmasın (Malatya, X16).

Sabır; sadece Allah'ın duyduğu bir duadır. Dualarımızı yaşatan Rabbime şükürler olsun (Sakarya, X5).

Alnı öpmek, alın yazısını öpmektir. Onun kaderine kefil, hayatına ortak olmaktır (Bolu, $\mathrm{X} 27)$.

Kaşı, gözü, gülüşü, bakışı, hatta kirpikleri bile benim için bilerek yaratılıp karşıma çıkarıldı sanki öyle güzel gönlümde (Antalya, X12).

Kirpiğine kadar sevdiğim adam, kokun cennetim, yüreğin en büyük servetim (Bursa, X3).

Sen cennetin yeryüzüne inişi, sen cenneti yâr yüzünde keşfedişimsin (Adana, X32).

Ve sevmek, sevdiğini emanet etmektir. Emanetleri kaybolmayan Allah’a (Konya, X1).

Dindar kadınlar eşlerine veya sevgililerine karşı duyduğu özel hislerini Instagram hesabındaki paylaşımlarıyla dile getirmektedirler. Paylaşımlarda aşkını helal söylemlerle dinselleştirerek göstermeye çalışmaktadırlar. Evli çiftler arasında olması gereken mahremiyet içerikli özel durumlar dijital alanda görsel ve metinsel şekilde Instagram'da paylaşılmaktadır. Sanal alanın kullanım kültürü aileyi ve aileye ait özel mahrem durumları mekan ötesi alanlarda tüketimsel gösterimin bir parçası olarak göstermektedir. Bunu yaparken yeni dini formları ve dini kimlikleri şekillendirmiştir. Dini kimlik ve dindarlık romantik imaj kazanarak dijital alanda yer 
kazanmıştır. Dindar kadın kullanıcıların Instagram paylaşımları, gündelik hayatının yanı sıra yaşadıkları ilişkilerini, aşklarını dini metinlerle göstermeye çalışmaktadır. Mahrem olarak görülen evlilik ritüelleri Instagram ile medyatik hale gelmektedir. Paylaşımlarda mahremiyeti if̧̧a etme endişesi yaşanmamaktadır. Bu nedenle sıklıkla mahrem duyguların Instagram'da paylaşılması dini söylemlerle ifade edilmektedir (Narmanlığlu, 2015).

\section{Sonuç}

İleri teknoloji ve internet kullanımının hakim olduğu yeni bir toplum modelini dijital toplum şeklinde kavramsallaştırmak beraberinde artık mikro ölçekteki her pratiği diji ön ekiyle isimlendirmeye yol açmıştır. Dijidindarlık, dijimahremiyet, dijiiletişim gibi kullanımlar bu yeni durumun söylemsel yansıması olarak ifade edilebilir. Fakat bu durum ortaya çıkarken toplumun bazı yapısal dönüşümler geçirmesinin sonucu olduğu unutulmamalıdır. Yani bu toplum modelinde yeni iletişim unsurlarının yer alması ve mekân-zaman bağlamında sınırların esnekleşmesi görünürlüğe doğru bir özelliği ortaya çıkarmıştır. Görünmenin kolaylaşması ve sınırların esnekleşmesi dijitalleşme ve dijital unsurlarının birer sonucudur. Çünkü görme ve gösterilme, birbirini denetleme durumu dijital toplumun temel özelliklerinden biri olmuştur. Görülmenin ve göstermenin dijital toplumda normalleşmesi bireylerin mahremiyet alanlarını değiştirmiştir. Dijital alanın unsurlarından biri olan sosyal medyada yer alan kullanıcılar birbirlerinin mahremiyetlerini kolaylıkla görebilme durumunu elde etmişlerdir. Temel anlamda gizliliğe dayalı olan mahremiyet, dijital alanda gösterme ve gösterilme üzerine yeni bir anlam üretmiştir. Dijitalleşen toplumda güzel olanı gösterme ve beğenilme gizliliği değersizleştirmiştir. Bu çerçevede gizlilikten öte güzel olanı gösterme hem değeri hem de popülerleşebilmeyi sağlamıştır. Özellikle de beğenilme ve popüler birer kimliğin kazanıldığı alan ise Instagram kullanımında gerçekleşmiştir.

Instagram, kullanım özellikleriyle görünme ve göstermeye dayalı bir sosyal medyadır. Instagram'ı kullanan bireyler kendilerini, benliklerini, sosyal yaşamdaki etnik rol ve statülerini paylaşımlarla göstermeye çalışmışlardır. Ayrıca hangi dini gruba mensup olduklarını ve hangi dini kimliği taşıdıklarını paylaşımlarla belirtmişlerdir. Instagram'da yer alan kullanıcılar profillerinde ve ana sayfalarında dini kimlikleri çerçevesinde dindarlıklarını paylaşımlarla ifade etmişlerdir. Bu paylaşımlar arasında Cuma gününün dini önemini ve ibadetini gösterebilmek amacıyla metinsel anlamda ayet ve hadislere, görsel anlamda ise cami, Kuran'ı Kerim ve Kabe'nin fotoğraflarının paylaşıldığı gözlemlenmiştir. Bununla birlikte dijital dindarlık olarak kavramsallaştırılan beden ve selfie paylaşımları oldukça dikkat çekici olmuştur. Dindar kadınlar Instagram kullanım kültüründe kendilerini güzel ve değerselleştirerek göstermeye çalışmışlardır. Çünkü paylaşımların sıklıkla yapılması Instagram'da beğeni ve yorum sayısını arttırarak fenomen dediğimiz dijital karakterleri ortaya çıkarmıştır. Fenomenleşen karakter arasında dindar kadınlar da yer alarak mahremiyet alanı olan beden ve bedene ait aksesuarlar görsel birer meta olarak kullanıldığı belirtilmiştir. Dijitalleşen beden ile birlikte toplumsal anlamda kurulan ilişkiler ve ritüeller de Instagram paylaşımları arasında yer almaktadır. Aile kurumuna ait olan söz, nişan, evlilik gibi toplumsal ritüeller Instagram'da sıklıkla paylaşılanlar arasındadır. Mahrem olarak değerlendirilen kadın-erkek arasındaki ilişkiler ve aile kavramını sembolleştiren toplumsal ri- 
tüeller dijitalleşme ile birlikte Instagram'da adeta söylemeye ve göstermeye dayalı normalleşen bir eyleme dönüşmüştür. Aile kurumuna ait özel mahrem ilişkiler dini anlamlar ve semboller ile romantikleştirilen gösterge haline gelmiştir. Örneklem olarak belirlenen dindar muhafazakâr kadınların yaptıkları Instagram paylaşımlarında günlük dini ritüellere, anlamlara ve ifadelere yer verdikleri sonucuna ulaşılmıştır. Dindar kadınlar Instagram kullanımında mahremiyet alanlarını şeffaf bir şekilde göstermeye çalışırken dini araçsallaştırarak dindarlıklarını dini sembol, söz ve anlamlarla yumuşatmaya çalıştıkları belirlenmiştir. Dindarlık dişsal bir görüntüyle Instagram'da gösterilirken gizlilik esasına dayalı mahremiyet anlayışı da görülebilen ve gösterilen bir alanı inşa etmiştir.

Dijitalleşme ve dijital etkileşimler sürekli kendini yenileyerek toplum üzerindeki etkisini hissettirecektir. Dijitalleşen toplumda hızlı yenilikler ve dönüşümler gerçekleşerek toplumsal kurumları da etkileyecektir. Bu kurumların başında önemle üzerinde durduğumuz din ve dini anlamlar dijitalleşme sürecinde hızlı bir değişime uğramıştır. Dindar bireyler dijitalleşme ile birlikte dini anlamları, sembolleri, dindarlığı geleneksel kalıpların dışına çıkartarak yeni tip dediğimiz göstermeye dayalı dijital yerlileri ortaya çıkarmıştır. Bu dijital yerliler dindar ve bilgiye hakim, bilgiyi kullanan ve hızlı ögrenen tiptir. Dijital alanda gösterdikleri dindarlık ve mahremiyet anlayışları da doğal olarak farklıdır. Dijital unsurların gündelik hayatın birer parçası haline gelerek kullanılması dindarlık ve mahremiyet ilişkisini etkileyecektir. Yapılan bu araştırmadan sonra mahremiyet anlayışları, söylemler, anlamlar dijital alanda değişerek yeniden üretilecektir. Dijital alanda gösterilen yeni mahremiyet anlayışlarının tespit edilip değerlendirilmesi konusunda yapılacak olan araştırmalara önerimiz dijitalleşmenin takip edilmesi ve bunun mahremiyet üzerindeki değişimini yorumlamaları önerilerimizden biridir.

\section{Kaynakça}

Aksan, D. (1998). “Mahremiyet”. Türk Dil Kurumu Sözlüğü. 2. Cilt. Ankara: Türk Dil Kurumu Yayınları. Atay, T. (2017). Görünüyorum O balde Varım. İstanbul: Can Yayınları.

Aktaş, C. (1995). Mahremiyetin Tükenişi. İstanbul: Nehir Yayınları.

Allport, G.W. (2004). Birey ve Dini. (Çev. Bilal Sambur). Ankara: Elis Yayınları.

Altunışık, R., Coşkun, R., Yıldırım, E.ve Bayraktaroğlu, S. (2010). Sosyal Bilimlerde Araștırma Yöntemleri. Sakarya: Kitabevi.

Aslanoğlu, H.N. (2016). Muhafazakâr Genç Kuşağın Instagram Profilleri: Mahremiyet, Moda ve Ahlakilik İlişkisi Üzerine Bir Değerlendirme. İlemblog, 1, 1-18.

Ayten, A. ve Köse, A. (2010). Türbeler Popüler Dindarlı̆̆ın Durakları. İstanbul: Timaş Yayınları.

Ayverdi, İ. (2005). “Mahremiyet Nedir?”. Kubbealtı LugatıMisalli Büyük Türkşe Sözlük. 3. Cilt. İstanbul: Kubbealt1 Yayınları.

Bauman, Z. (2013). Akı̧skan Modernite. (Çev. Sinan Okan Çavuş). İstanbul: Can Yayınları.

Bauman, Z. (2016). Modernite ve Holokaust. (Çev. Süha Sertabiboğlu). İstanbul: Alfa Yayınları.

Bauman, Z.ve Lyon, D. (2017).Akışkan Gözetim. 2.Baskı. (Çev. Elçin Y1lmaz).İstanbul: Ayrıntı Yayınları.

Canbulat,M.(2018). “Cuma Günü ve Cuma Namazı”.Diyanet İşleri Başkanlığı.Erişim:28Temmuz2018, https://www2.diyanet.gov.tr/DinHizmetleriGenelMudurlugu/VaazProjeleri/Cuma\%20 G\%C3\%BCn\%C3\%BC\%20ve\%20Cuma\%20Namaz\%C4\%B1.pdf 
Çapcıoğlu, İ. ve Akın, M. (2019), "Sosyal Medya ve Yeni Risk Alanları: Mahremiyet Bağlamında Özel yaşamın Dönüşümü”, Editör: İhsan Çapcıŏlu, 6. Uluslararası Din Bilimleri Sempozyumu Tam Metin Kitabı, 7-11, Elazığ: Asos Yayınları.

Çapçıŏlu, İ. (2019). Sosyal Medya, 'Yeni İnsan Tipi' ve Etik Sorunlar. II. Uluslararası İnsan ve Toplum Bilimleri Araştrrma Kongresi (İTOB亡̇AD), 658-668.

Çağbayır, Y. (2017). “Mahremiyet”. Ötüken Türkşe Sözlüğ̈̈. 5. cilt. 2. Baskı. İstanbul: Ötüken Yayınları.

Dalkıç Örs, Ö. (2018). Mahremiyet ve Instagram Mahremiyetinin İnsanın Yaşam Olgusuna Etkileri. Yayınlanmamış Yüksek Lisans Tezi. Fırat Üniversitesi Sosyal Bilimler Enstitüsü, Elâzığ.

Dolgun, U. (2008). Şeffaf Hapishane Yahut Gözetim Toplumu. 3. Baskı. İstanbul: Ötüken Yayınları.

Foucault, M. (2012). Hapishanenin Doğuşu. (Çev. Mehmet Ali Kilıçbay). İstanbul: İmge Kitabevi.

Giddens, A. (2014). Mahremiyetin Dönüşümü. (Çev. İdris Şahin). İstanbul: Ayrıntı Yayınları.

Göle, N. (2016). Modern Mahrem. 13. Baskı. İstanbul: Metis Yayıncılık.

Han, B.C. (2018). Şeffaflık Toplumu. (Çev. Haluk Barışcan). İstanbul: Metis Yayınları.

Harman, Ö.F. (1997). "Harun”. Türkiye Diyanet Vakfi İslâm Ansiklopedisi. 11. Cilt. İstanbul: TDV Yayınları.

Hekimoğlu, H. (2019). Sosyal Ağlarda Mahremiyetin Dönüşümü: Instagram Örneği. Yayınlanmamı̧̧ Yüksek Lisans Tezi. Erciyes Üniversitesi Sosyal Bilimler Enstitüsü, Kayseri.

Janmohamed, S. (2018). M Nesli: Yeni Müslüman Gençlik. (Çev. Esin Kız1lelma). İstanbul: Kaknüs Yayınlar1.

Kurt, A. (2009). Dindarlığ1 Etkileyen Faktörler. Uludağ Üniversitesi İlabiyat Fakültesi Dergisi, 18(2), 1-26.

Narmanlığlu, H. (2015). Sanal Cemaatte Çevrimiçi İbadet. Editör: Mete Çamdereli, Betül Önay Doğan, Nihal Kocabay Şener. Dijitalleşen Din: Medya ve Din 2, 69-108. İstanbul: Köprü Kitap.

Okumuş, E. (2012). Gösteriş̧̧ Dindarlık. 2. Baskı. İstanbul: Ark Yayınları.

Öktem, Ü. (2005). Fenomenoloji ve Edmund Husserl'de Apaç1klık (Evıdenz) Problemi. Ankara Üniversitesi Dil ve Tarih-Coğrafya Fakültesi Dergisi, 45 (1), 27-55.

Özel, E. (2018). Helal Aşkın Halleri. Nibayet Dergisi, 38, 22-26.

Öztekin, H.ve Öztekin, A. (2010). Modernleşme-Mahremiyet İlişkisi ve Siber Mekânda Mahremiyetin Aleniyete Dönüşmesi. E-Journal Nerw World Science Academy (NWSA), 5(4), 526-540.

Saad, G. (2012). Tüketim İçü̈ü̈ü: Neden Ferrari, Fast-Food ve Porno Seviyoruz? (Çev. Nadir Özata). İstanbul: Mediacat Kitaplar1.

Simmel, G. (2015). Modern Kültürde Çatışma. 10. Baskı. (Çev. Tanıl Bora). İstanbul: İletişim Yayınları. Şişman, N. (2019). Mahremiyet Hayatın Sırları ve Sınırları. İstanbul: İnsan Yayınları.

Uzundumlu, Ö. (2015) Bir İletişsim Formu Olarak Sosyal Medyada Fotoğraf Paylaşımı: Selfie Örneği. Yayınlanmamış Yüksek Lisans Tezi. Atatürk Üniversitesi Sosyal Bilimler Enstitüsü, Erzurum.

Vincent, D. (2016). Mahremiyet Kısa Bir Tarih. (Çev. Deniz Cumhur Başaraner). İstanbul: Epos Yayınlar1.

Yaman, A. (2011). "Mahremiyet”. Türkiye Diyanet Vakfi Íslam Ansiklopedisi. 2. Cilt. Ankara: TDV Yayınları.

Yavuz, H. (2012). Budalalılı̆̆ın Keşffi. İstanbul: Timaş Yayınlar.

Yüksel, M. (2003). Mahremiyet Hakkı ve Sosyo-Tarihsel Gelişimi. Ankara Üniversitesi SBF Dergisi, 58(1), 181-213.

Zorlu, A. (2006). Modern Tüketim Taribinden Tüketim Araştırmalarna Tüketim Sosyolojisi. Ankara: Global Yayıncilik. 


$$
\text { NR? }
$$

